\title{
Effect of Various Training Systems and Spacings on Flowering and Fruiting in Peach cv. Shan-i-Punjab
}

\author{
Yamini Sharma* and Harminder Singh
}

KVK Gurdaspur, Punjab Agricultural University, Ludhiana, India

*Corresponding author

\begin{tabular}{l} 
Ke y w o r d s \\
$\begin{array}{l}\text { Flowering and } \\
\text { fruiting in peach, } \\
\text { Shan-i-Punjab }\end{array}$ \\
\hline Article Info \\
\hline $\begin{array}{l}\text { Accepted: } \\
\text { 07 January } 2018 \\
\text { Available Online: } \\
\text { 10 February } 2018\end{array}$ \\
\hline
\end{tabular}

A B S T R A C T

Trees of Shan-i-Punjab peach were planted at two spacings viz., $5 \mathrm{~m}$ x $2 \mathrm{~m}$ and $5 \mathrm{~m} \times 3 \mathrm{~m}$ and were trained to four training systems viz., $\mathrm{Y}$ shaped, Hedge row, Espalier and $\mathrm{V}$ trellis. Maximum mean flower bud density (13.95) was recorded in $\mathrm{V}$ trellis trained trees and minimum mean flower bud density was recorded in Hedge row trees. Fruiting characters including fruit set, fruit retention, fruiting pattern was maximum in Espailer trained trees and minimum in Hedge row trees. Maximum fruit drop was found in Hedge row trees and minimum in Espailer trees. Trees planted at $5 \mathrm{~m} \mathrm{X} \mathrm{3m}$ gave higher Flower bud density, Fruit set, Fruit retention, Fruit drop as compared to $5 \mathrm{~m} \mathrm{X} 2 \mathrm{~m}$ planted trees. It was also observed that in upper canopy part maximum flower bud density, Fruit set, Fruit retention and fruiting pattern was observed whereas in lower canopy part there was maximum fruit drop.

\section{Introduction}

Peaches grow in a fairly limited range in dry, continental or temperate climates, since the trees have a chilling requirement that tropical or sub-tropical areas generally cannot satisfy except in some parts of Uttarakhand, parts of Uttar Pradesh, Tamil Nadu, North Eastern states, Punjab and Haryana (Pathak and Pathak, 2001). Most cultivars require 500 hours of chilling $\left(0\right.$ to $\left.10^{\circ} \mathrm{C}\right)$ and during that period plant remains in dormant but still chemical reactions are taking place. It is known that peach is highly vigorous fruit crop and in peach no size controlling rootstock is optimal for all climatic conditions, cultivars and economic situation (Yoshikawa et al., 1989). Out of that reason different systems were studied worldwide in accordance with the specific characteristics of the fruit-growing countries and regions (Van Den Ende et al., 1987).

\section{Materials and Methods}

The present study was conducted at Fruit Research Farm of the Department of Fruit Science, Punjab Agricultural University, 
Ludhiana during the years 2014 and 2015. Peach trees of cv. Shan-i-Punjab were planted at two spacings i.e. $5 \mathrm{~m} \times 2 \mathrm{~m}$ and $5 \mathrm{~m} \times 3 \mathrm{~m}$ and were trained to four training system viz., $Y$ shaped, Hedge row, Espalier and V trellis. Trees were pruned every year in winter and it consisted of a combination of heading back and selective thinning out of fruitful branches. The orchard soil was deep, well drained and loamy sand. All the trees received recommended doses of fertilizers $(500 \mathrm{~g} \mathrm{~N}$, $120 \mathrm{~g}_{2} \mathrm{O}_{5}$ and $500 \mathrm{~K}_{2} \mathrm{O}$ ) and other cultural practices during the course of these investigations. The observations on flowering (Flower bud density, Fruit set, Fruit retention, Fruit drop and Relative pattern of fruiting in the tree canopy were recorded as per the standard procedure used in such studies. The data was subjected to analysis of variance (ANOVA) using statistical software SAS. The mean separation was done using least significant difference (Fisher's LSD) at $\leq 0.05$ following significant $F$ test.

\section{Flower and fruit characters}

\section{Flower bud density}

Data on this aspect in Table 1 reveal that flower bud density was significantly affected by training systems in peach during the present studies. Mean flower bud density was significantly more in the year 2014 as compared to 2015, irrespective of training systems and spacings. This was may be due to the reason that heavy pruning was done to restrict the growth of the tree so that intermingling of shoots can be avoided. Trees trained to $\mathrm{V}$ trellis recorded maximum mean flower bud density of 13.95. It was followed by $\mathrm{Y}$ shaped trees which recorded mean flower bud density of 11.84. Minimum mean flower bud density was recorded in Hedge row trees (10.84) which were statistically at par with trees trained to Espailer system (10.96). Minimum flower bud density in Hedge row system might be due to poor illumination and in Espailer trees due to heavy pruning done to restrict the trees from intermingling with each other during the present studies. Dyankov (1995) reported that more severe pruning increased the number of active growing points and extension shoots in the tree reducing flower bud formation. The negative effect of pruning on flowering in apple was also reported by Davis (1957) and Mika and Piatkowski (1986). Maximum flower bud density in $\mathrm{V}$ trellis was apparently due to proper distribution of light in inner parts of canopy and presence of thicker shoots and trunk in which increased more carbohydrate accumulation.

Data further shows that mean flower bud density in $5 \mathrm{~m} \times 3 \mathrm{~m}$ (12.76) planted trees was significantly more than the trees planted at $5 \mathrm{~m}$ $\mathrm{x} 2 \mathrm{~m}$ (11.03), irrespective of the training system and parts of the tree canopy. This may be attributed to reduced radiant energy received and reduced substrate level with reduction in shoots growth or an increase in gibberellin level. The present results are in accordance with those reported by Mika et al., (1981) in apple; Ristevski (1982) in pear and Singh (2003) in guava Data on Table 1 further shows that mean flower bud density in upper canopy were higher as compared to lower parts in all the training systems and spacings during both the years. In the upper part, maximum flower bud density was obtained in $\mathrm{V}$ trellis (16.80) and minimum in Hedge row (11.30) trees. Similarly in the lower canopy part, maximum flower bud density was again recorded in $\mathrm{V}$ trellis (11.10) and minimum in Hedge row trees (7.38). The lower part of the canopy had the minimum flower bud density in all the four training systems studied. It was may be due to comparatively reduced radiation penetration in the lower part of the tree canopy. Heinicke (1963) reported that availability of proper sunlight to the lower branches of a tree became a limiting factor 
thus it adversely affected flower bud differentiation. Low flower bud density may be due to reduced substrate level with reduction in shoot growth (Jackson and Palmer, 1977) or an increase in gibberellin level as indicated by changes in leaf and shoot morphology.

\section{Fruit set}

The perusal of data in Table 2 reveals that mean fruit set was significantly more during 2014 as compared to 2015 in all the training systems and spacings during the present studies. It was apparently due to heavy rain and storms at the time of flowering during 2015. Trees trained to Espailer system recorded maximum mean fruit set of 78.75 per cent and it was statistically at par with trees trained to $\mathrm{V}$ trellis $(78.18 \%)$. Minimum mean fruit set $(73.59 \%)$ was recorded in Hedge row system. The general effect of training systems on fruit set was true for year wise effects also. Higher fruit set in Espailer system and V trellis trained trees was may be due to better distribution of light within the tree canopy. Doud and Ferree (1980) also found that significant reduction in light levels in the canopies reduced fruit set. Data also shows that maximum mean fruit set $(77.82 \%)$ was recorded in $5 \mathrm{~m} \times 3 \mathrm{~m}$ planted trees and it was significantly higher than the trees planted at $5 \mathrm{~m} \times 2 \mathrm{~m}(76.48 \%)$, irrespective of the training systems and parts of the tree canopy. Similar trend was observed during the years 2014 and 2015 also. The lower fruit set at $5 \mathrm{~m} \times 2 \mathrm{~m}$ planted trees may be due less light and air circulation inside the canopy. Lower fruit set in closely planted trees has been reported in olive by Li et al., (2013).

As far as fruit set in different canopy parts are concerned, the data in Table 2 show that fruit set in upper canopy parts was higher as compared to lower parts irrespective of training systems, spacings and year.
Maximum fruit set in both upper and lower canopy parts was recorded in Espailer system (82.73\% and $74.78 \%$, respectively). Lesser fruit set in lower parts of the tree canopy was due to decrease in radiation interception in these parts. Jackson and Palmer (1977) found that reduced fruit set by shading treatment in apple might be due to depletion of reserve carbohydrates and minerals available for translocation from storage tissues at the time when current photosynthesis was limited by shade and small leaf area.

\section{Fruit retention}

Data on this aspect in Table 3 show that maximum fruit retention in peach tree was recorded in Espailer system (56.01\%) and it was significantly higher than the trees trained to all other training system. Minimum mean fruit retention was recorded in $(53.32 \%)$ Hedge row trained trees. Maximum fruit retention in Espailer system may be due to more accumulation of photosynthates leading to more carbohydrate production and increased auxin level which delayed the formation of abscission layer.

Similar findings were reported by Addicot and Lynch (1955) and Jackson (1978) in apple. Data further shows that maximum mean fruit retention $(55.15 \%)$ was recorded in trees planted at $5 \mathrm{~m} \times 3 \mathrm{~m}$ and it was significantly higher than $5 \mathrm{~m} \times 2 \mathrm{~m}$ planted trees $(53.89 \%)$, irrespective of the training systems and parts of the canopy.

This may be due to less tree spread at close spacings which reduced the light creating the uncongenial microclimate within the tree canopy and decreased fruit retention. These findings are in accordance with those of Byers et al., (1991) who reported that apple plants which were kept in artificial shade decreased fruit retention by forming abscission layer in fruits. 
Table.1 Effect of training systems and spacings on flower bud density (number of flower buds/ meter of shoot length) of peach cv. Shan-i-Punjab

\begin{tabular}{|c|c|c|c|c|c|c|c|c|c|c|}
\hline \multirow[t]{2}{*}{ Training Systems } & \multirow[t]{2}{*}{ Spacings (m) } & \multicolumn{3}{|c|}{ Upper canopy part } & \multicolumn{3}{|c|}{ Lower canopy part } & \multicolumn{3}{|c|}{ Mean } \\
\hline & & 2014 & 2015 & Mean & 2014 & 2015 & Mean & 2014 & 2015 & Mean \\
\hline \multirow[t]{3}{*}{ Y shaped } & $5 \times 2$ & 15.18 & 12.85 & 14.01 & 8.33 & 7.58 & 7.96 & 11.76 & 10.22 & 10.99 \\
\hline & $5 \times 3$ & 16.02 & 13.82 & 14.92 & 10.49 & 10.40 & 10.45 & 13.26 & 12.12 & 12.69 \\
\hline & Mean & $15.60^{b}$ & $13.33^{c}$ & $14.47^{b}$ & $9.41^{b}$ & $8.99^{b}$ & $9.20^{b}$ & $12.51^{b}$ & $11.17^{b}$ & $11.84^{b}$ \\
\hline \multirow[t]{3}{*}{ Hedge row } & $5 \times 2$ & 13.33 & 13.57 & 13.45 & 6.63 & 6.50 & 6.56 & 9.98 & 10.03 & 10.00 \\
\hline & $5 \times 3$ & 15.21 & 15.09 & 15.15 & 8.43 & 7.96 & 8.19 & 11.82 & 11.52 & 11.67 \\
\hline & Mean & $14.27^{c}$ & $14.33^{b}$ & $14.30^{b}$ & $7.53^{c}$ & $7.23^{d}$ & $7.38^{c}$ & $10.90^{d}$ & $10.78^{b c}$ & $10.84^{c}$ \\
\hline \multirow[t]{3}{*}{ Espailer } & $5 \times 2$ & 14.69 & 12.08 & 13.39 & 6.28 & 7.26 & 6.77 & 10.49 & 9.67 & 10.08 \\
\hline & $5 \times 3$ & 16.19 & 13.97 & 15.08 & 8.68 & 8.53 & 8.61 & 12.44 & 11.25 & 11.84 \\
\hline & Mean & $15.44^{b}$ & $13.02^{c}$ & $14.23^{b}$ & $7.48^{c}$ & $7.89^{c}$ & $7.69^{c}$ & $11.46^{c}$ & $10.46^{c}$ & $10.96^{\mathrm{c}}$ \\
\hline \multirow[t]{3}{*}{ V trellis } & $5 \times 2$ & 16.05 & 15.93 & 15.99 & 10.41 & 9.90 & 10.15 & 13.23 & 12.92 & 13.07 \\
\hline & $5 \times 3$ & 17.50 & 17.67 & 17.61 & 12.93 & 11.17 & 12.05 & 15.25 & 14.42 & 14.83 \\
\hline & Mean & $16.80^{\mathrm{a}}$ & $16.80^{a}$ & $16.80^{\mathrm{a}}$ & $11.67^{\mathrm{a}}$ & $10.53^{a}$ & $11.10^{\mathrm{a}}$ & $14.24^{\mathrm{a}}$ & $13.67^{\mathrm{a}}$ & $13.95^{\mathrm{a}}$ \\
\hline \multirow[t]{2}{*}{ Spacing mean } & $5 \times 2$ & $14.81^{b}$ & $13.61^{b}$ & $14.21^{b}$ & $7.91^{\mathrm{b}}$ & $7.81^{\mathrm{b}}$ & $7.86^{\mathrm{b}}$ & $11.37^{\mathrm{b}}$ & $10.71^{\mathrm{b}}$ & $11.03^{b}$ \\
\hline & $5 \times 3$ & $16.24^{\mathrm{a}}$ & $15.14^{\mathrm{a}}$ & $15.69^{\mathrm{a}}$ & $10.13^{\mathrm{a}}$ & $9.52^{\mathrm{a}}$ & $9.82^{\mathrm{a}}$ & $13.19^{\mathrm{a}}$ & $12.33^{\mathrm{a}}$ & $12.76^{\mathrm{a}}$ \\
\hline \multirow[t]{3}{*}{ LSD 0.05} & Training system & 0.62 & 0.63 & 0.42 & 0.32 & 0.57 & 0.15 & 0.32 & 0.42 & 0.26 \\
\hline & Spacing & 0.44 & 0.45 & 0.30 & 0.23 & 0.40 & 0.22 & 0.22 & 0.30 & 0.18 \\
\hline & TS x Spacing & 0.88 & 0.90 & 0.60 & 0.46 & 0.81 & 0.44 & 0.45 & 0.60 & 0.36 \\
\hline
\end{tabular}


Table.2 Effect of training systems and spacings on fruit set (\%) of peach cv. Shan-i-Punjab

\begin{tabular}{|c|c|c|c|c|c|c|c|c|c|c|}
\hline \multirow[t]{2}{*}{ Training Systems } & \multirow[t]{2}{*}{ Spacings (m) } & \multicolumn{3}{|c|}{ Upper canopy part } & \multicolumn{3}{|c|}{ Lower canopy part } & \multicolumn{3}{|c|}{ Mean } \\
\hline & & 2014 & 2015 & Mean & 2014 & 2015 & Mean & 2014 & 2015 & Mean \\
\hline \multirow[t]{3}{*}{ Y shaped } & $5 \times 2$ & 85.74 & 75.95 & 80.84 & 78.70 & 69.42 & 74.06 & 82.22 & 72.68 & 77.45 \\
\hline & $5 \times 3$ & 86.60 & 77.38 & 81.99 & 79.91 & 70.92 & 75.41 & 83.26 & 74.15 & 78.70 \\
\hline & Mean & $86.17^{a}$ & $76.66^{a}$ & $81.42^{a}$ & $79.30^{\mathrm{a}}$ & $70.17^{a}$ & $74.74^{a}$ & $82.74^{a}$ & $73.42^{a}$ & $78.08^{b}$ \\
\hline \multirow[t]{3}{*}{ Hedge row } & $5 \times 2$ & 80.58 & 72.57 & 76.57 & 70.64 & 66.67 & 68.65 & 75.61 & 69.62 & 72.61 \\
\hline & $5 \times 3$ & 83.61 & 74.11 & 78.86 & 72.52 & 68.05 & 70.28 & 78.06 & 71.07 & 74.57 \\
\hline & Mean & $82.09^{b}$ & $73.34^{b}$ & $77.71^{b}$ & $71.52^{b}$ & $67.36^{b}$ & $69.47^{b}$ & $76.83^{b}$ & $70.35^{b}$ & $73.59^{c}$ \\
\hline \multirow[t]{3}{*}{ Espailer } & $5 \times 2$ & 86.91 & 77.58 & 82.25 & 78.07 & 70.03 & 74.05 & 82.49 & 73.81 & 78.15 \\
\hline & $5 \times 3$ & 87.65 & 78.76 & 83.20 & 79.11 & 71.92 & 75.51 & 83.38 & 75.34 & 79.35 \\
\hline & Mean & $87.28^{\mathrm{a}}$ & $78.17^{\mathrm{a}}$ & $82.73^{a}$ & $78.59^{a}$ & $70.97^{a}$ & $74.78^{\mathrm{a}}$ & $82.93^{a}$ & $74.57^{\mathrm{a}}$ & $78.75^{\mathrm{a}}$ \\
\hline \multirow[t]{3}{*}{ V trellis } & $5 \times 2$ & 85.93 & 76.64 & 81.28 & 78.69 & 69.52 & 74.10 & 82.31 & 73.08 & 77.69 \\
\hline & $5 \times 3$ & 86.60 & 78.42 & 82.51 & 79.46 & 70.20 & 74.83 & 83.03 & 74.31 & 78.67 \\
\hline & Mean & $86.25^{a}$ & $77.53^{a}$ & $81.89^{a}$ & $79.08^{a}$ & $69.86^{a}$ & $74.47^{\mathrm{a}}$ & $82.67^{a}$ & $73.70^{a}$ & $78.18^{a b}$ \\
\hline \multirow[t]{2}{*}{ Spacing mean } & $5 \times 2$ & $84.79^{a}$ & $75.69^{a}$ & $80.24^{\mathrm{b}}$ & $76.52^{b}$ & $68.91^{\mathrm{b}}$ & $72.72^{b}$ & $80.65^{b}$ & $72.30^{\mathrm{b}}$ & $76.48^{b}$ \\
\hline & $5 \times 3$ & $86.11^{\mathrm{a}}$ & $77.17^{\mathrm{a}}$ & $81.64^{\mathrm{a}}$ & $77.75^{\mathrm{a}}$ & $70.27^{\mathrm{a}}$ & $74.01^{\mathrm{a}}$ & $81.93^{\mathrm{a}}$ & $73.72^{a}$ & $77.82^{\mathrm{a}}$ \\
\hline \multirow[t]{3}{*}{ LSD 0.05} & Training system & 2.46 & 2.10 & 1.59 & 0.90 & 1.31 & 0.77 & 1.29 & 1.28 & 0.58 \\
\hline & Spacing & 1.74 & 1.48 & 1.12 & 0.63 & 0.92 & 0.544 & 0.91 & 0.90 & 0.41 \\
\hline & TS x Spacing & 3.48 & 2.97 & 2.25 & 1.27 & 1.85 & 1.08 & 1.83 & 1.81 & 0.82 \\
\hline
\end{tabular}


Table.3 Effect of training systems and spacings on fruit retention (\%) in peach cv. Shan-i-Punjab

\begin{tabular}{|c|c|c|c|c|c|c|c|c|c|c|}
\hline \multirow[t]{2}{*}{ Training Systems } & \multirow[t]{2}{*}{ Spacings (m) } & \multicolumn{3}{|c|}{ Upper canopy part } & \multicolumn{3}{|c|}{ Lower canopy part } & \multicolumn{3}{|c|}{ Mean } \\
\hline & & 2014 & 2015 & Mean & 2014 & 2015 & Mean & 2014 & 2015 & Mean \\
\hline \multirow[t]{3}{*}{ Y shaped } & $5 \times 2$ & 52.83 & 57.08 & 54.95 & 50.75 & 53.13 & 51.94 & 51.78 & 55.10 & 53.44 \\
\hline & $5 \times 3$ & 53.82 & 58.91 & 56.36 & 51.36 & 54.18 & 52.77 & 52.59 & 56.60 & 54.57 \\
\hline & Mean & $53.32^{b c}$ & $57.99^{b}$ & $55.66^{b c}$ & $51.05^{b}$ & $53.65^{c}$ & $52.35^{b}$ & $52.19^{b}$ & $55.82^{c}$ & $54.00^{c}$ \\
\hline \multirow[t]{3}{*}{ Hedge row } & $5 \times 2$ & 51.20 & 56.96 & 54.08 & 48.74 & 52.86 & 50.80 & 49.97 & 54.91 & 52.44 \\
\hline & $5 \times 3$ & 52.99 & 59.17 & 56.08 & 50.80 & 53.90 & 52.35 & 51.89 & 56.53 & 54.21 \\
\hline & Mean & $52.09^{c}$ & $58.06^{b}$ & $55.08^{c}$ & $49.11^{c}$ & $53.38^{c}$ & $51.57^{\mathrm{c}}$ & $50.93^{c}$ & $55.72^{c}$ & $53.32^{d}$ \\
\hline \multirow[t]{3}{*}{ Espailer } & $5 \times 2$ & 54.33 & 59.22 & 56.78 & 52.23 & 55.67 & 53.95 & 53.28 & 57.45 & 55.36 \\
\hline & $5 \times 3$ & 56.33 & 60.27 & 58.30 & 53.33 & 56.69 & 55.01 & 54.83 & 58.48 & 56.65 \\
\hline & Mean & $55.33^{\mathrm{a}}$ & $59.75^{\mathrm{a}}$ & $57.54^{a}$ & $52.78^{a}$ & $56.18^{a}$ & $54.48^{a}$ & $54.05^{\mathrm{a}}$ & $57.96^{a}$ & $56.01^{a}$ \\
\hline \multirow[t]{3}{*}{ V trellis } & $5 \times 2$ & 53.46 & 58.42 & 55.94 & 50.53 & 54.79 & 52.66 & 51.99 & 56.60 & 54.30 \\
\hline & $5 \times 3$ & 54.65 & 59.37 & 57.01 & 51.17 & 55.52 & 53.35 & 52.91 & 57.44 & 55.57 \\
\hline & Mean & $54.05^{a b}$ & $59.90^{\mathrm{ab}}$ & $56.47^{b}$ & $50.85^{b}$ & $55.15^{b}$ & $53.00^{b}$ & $52.45^{b}$ & $57.02^{b}$ & $54.74^{b}$ \\
\hline \multirow[t]{2}{*}{ Spacing mean } & $5 \times 2$ & $52.95^{\mathrm{b}}$ & $57.92^{b}$ & $55.44^{\mathrm{b}}$ & $50.56^{\mathrm{b}}$ & $54.11^{b}$ & $52.34^{\mathrm{b}}$ & $51.75^{\mathrm{b}}$ & $56.01^{\mathrm{b}}$ & $53.89^{b}$ \\
\hline & $5 \times 3$ & $54.45^{\mathrm{a}}$ & $59.43^{\mathrm{a}}$ & $56.94^{\mathrm{a}}$ & $51.66^{\mathrm{a}}$ & $55.07^{\mathrm{a}}$ & $53.37^{\mathrm{a}}$ & $53.05^{\mathrm{a}}$ & $57.25^{\mathrm{a}}$ & $55.15^{\mathrm{a}}$ \\
\hline \multirow[t]{3}{*}{ LSD 0.05} & Training system & 1.53 & 1.18 & 0.92 & 1.02 & 0.01 & 0.73 & 0.76 & 0.82 & 0.48 \\
\hline & Spacing & 1.09 & 0.83 & 0.65 & 0.72 & 0.71 & 0.51 & 0.53 & 0.58 & 0.34 \\
\hline & TS x Spacing & 2.19 & 1.67 & 1.30 & 1.44 & 1.43 & 1.03 & 1.07 & 1.17 & 0.68 \\
\hline
\end{tabular}


Table.4 Effect of training systems and spacings on fruit drop (\%) in peach cv. Shan-i-Punjab

\begin{tabular}{|c|c|c|c|c|c|c|c|c|c|c|}
\hline \multirow[t]{2}{*}{ Training Systems } & \multirow[t]{2}{*}{ Spacings (m) } & \multicolumn{3}{|c|}{ Upper canopy part } & \multicolumn{3}{|c|}{ Lower canopy part } & \multicolumn{3}{|c|}{ Mean } \\
\hline & & 2014 & 2015 & Mean & 2014 & 2015 & Mean & 2014 & 2015 & Mean \\
\hline \multirow[t]{3}{*}{ Y shaped } & $5 \times 2$ & 47.17 & 42.92 & 45.05 & 49.25 & 46.87 & 48.06 & 48.22 & 44.90 & 46.56 \\
\hline & $5 \times 3$ & 46.18 & 41.09 & 43.64 & 48.64 & 45.82 & 47.23 & 47.41 & 43.40 & 45.43 \\
\hline & Mean & $46.68^{a}$ & $42.01^{a}$ & $44.35^{\mathrm{a}}$ & $48.95^{b}$ & $46.35^{b}$ & $47.65 b^{c}$ & $47.82^{a}$ & $44.15^{a}$ & $46.00^{c}$ \\
\hline \multirow[t]{3}{*}{ Hedge row } & $5 \times 2$ & 48.80 & 43.04 & 45.92 & 51.26 & 47.14 & 49.20 & 50.03 & 45.09 & 47.56 \\
\hline & $5 \times 3$ & 47.01 & 40.83 & 43.92 & 49.20 & 46.10 & 47.65 & 48.11 & 43.47 & 45.79 \\
\hline & Mean & $47.91^{a}$ & $41.94^{a}$ & $44.92^{\mathrm{a}}$ & $50.23^{\mathrm{a}}$ & $46.62^{a}$ & $48.43^{\mathrm{a}}$ & $49.07^{\mathrm{a}}$ & $44.28^{\mathrm{a}}$ & $46.68^{d}$ \\
\hline \multirow[t]{3}{*}{ Espailer } & $5 \times 2$ & 45.67 & 40.78 & 43.22 & 47.77 & 44.33 & 46.05 & 46.72 & 42.55 & 44.64 \\
\hline & $5 \times 3$ & 43.67 & 39.73 & 41.70 & 46.67 & 43.31 & 44.99 & 45.17 & 41.52 & 43.35 \\
\hline & Mean & $44.67^{b}$ & $40.26^{b}$ & $42.46^{b}$ & $47.22^{c}$ & $43.82^{c}$ & $45.52^{d}$ & $45.95^{c}$ & $42.04^{c}$ & $44.00^{a}$ \\
\hline \multirow[t]{3}{*}{ V trellis } & $5 \times 2$ & 46.54 & 41.58 & 44.06 & 49.47 & 45.21 & 47.34 & 48.01 & 43.40 & 45.70 \\
\hline & $5 \times 3$ & 45.35 & 40.63 & 42.99 & 48.83 & 44.48 & 46.65 & 47.09 & 42.56 & 44.43 \\
\hline & Mean & $45.95^{a}$ & $41.11^{a b}$ & $43.53^{b}$ & $49.15^{b}$ & $44.85^{c}$ & $47.00^{c}$ & $47.55^{b}$ & $42.98^{b}$ & $45.07^{b}$ \\
\hline \multirow[t]{2}{*}{ Spacing mean } & $5 \times 2$ & $47.05^{\mathrm{a}}$ & $42.08^{\mathrm{a}}$ & $44.56^{\mathrm{a}}$ & $49.44^{\mathrm{a}}$ & $45.89^{\mathrm{a}}$ & $47.66^{\mathrm{a}}$ & $48.25^{\mathrm{a}}$ & $43.99^{\mathrm{a}}$ & $46.12^{\mathrm{a}}$ \\
\hline & $5 \times 3$ & $45.55^{b}$ & $40.57^{b}$ & $43.06^{\mathrm{b}}$ & $48.34^{b}$ & $44.93^{b}$ & $46.63^{b}$ & $46.95^{b}$ & $42.74^{b}$ & $44.75^{b}$ \\
\hline \multirow[t]{3}{*}{ LSD 0.05} & Training system & 1.28 & 1.18 & 1.20 & 0.90 & 1.31 & 0.76 & 1.29 & 0.94 & 0.58 \\
\hline & Spacing & 1.74 & 1.48 & 0.85 & 0.63 & 0.92 & 0.54 & 0.91 & 0.90 & 0.41 \\
\hline & TS x Spacing & 3.48 & 2.97 & 1.71 & 1.27 & 1.85 & 1.08 & 1.83 & 1.81 & 0.82 \\
\hline
\end{tabular}


Table.5 Effect of training systems and spacings on fruiting pattern (\%) of peach cv. Shan-i-Punjab

\begin{tabular}{|c|c|c|c|c|c|c|c|}
\hline \multirow{2}{*}{$\begin{array}{l}\text { Training } \\
\text { Systems }\end{array}$} & \multirow[t]{2}{*}{ Spacings (m) } & \multicolumn{3}{|c|}{ Upper canopy part } & \multicolumn{3}{|c|}{ Lower canopy part } \\
\hline & & 2014 & 2015 & Mean & 2014 & 2015 & Mean \\
\hline \multirow[t]{3}{*}{ Y shaped } & $5 \times 2$ & 52.38 & 55.63 & 54.00 & 48.18 & 45.62 & 46.90 \\
\hline & $5 \times 3$ & 53.43 & 54.76 & 54.09 & 47.56 & 46.72 & 47.13 \\
\hline & Mean & $52.90^{c}$ & $55.19^{c}$ & $54.05^{c}$ & $47.86^{b}$ & $46.17^{b}$ & $47.01^{b}$ \\
\hline \multirow[t]{3}{*}{ Hedge row } & $5 \times 2$ & 62.43 & 70.49 & 66.46 & 38.44 & 30.53 & 34.48 \\
\hline & $5 \times 3$ & 65.43 & 68.55 & 66.93 & 35.52 & 32.67 & 34.09 \\
\hline & Mean & $63.88^{\mathrm{a}}$ & $69.52^{\mathrm{a}}$ & $66.70^{\mathrm{a}}$ & $36.98^{d}$ & $31.60^{d}$ & $34.29^{d}$ \\
\hline \multirow[t]{3}{*}{ Espailer } & $5 \times 2$ & 53.51 & 56.50 & 55.00 & 47.67 & 44.44 & 46.05 \\
\hline & $5 \times 3$ & 54.47 & 55.54 & 55.00 & 46.52 & 45.48 & 45.99 \\
\hline & Mean & $53.99^{b}$ & $56.02^{b}$ & $55.00^{b}$ & $47.09^{c}$ & $44.96^{c}$ & $46.02^{c}$ \\
\hline \multirow[t]{3}{*}{$\mathrm{V}$ trellis } & $5 \times 2$ & 52.03 & 53.40 & 52.72 & 49.26 & 45.50 & 47.37 \\
\hline & $5 \times 3$ & 50.88 & 52.55 & 51.71 & 50.21 & 48.28 & 49.24 \\
\hline & Mean & $51.46^{d}$ & $52.98^{d}$ & $52.21^{d}$ & $49.73^{\mathrm{a}}$ & $46.89^{a}$ & $48.31^{\mathrm{a}}$ \\
\hline \multirow[t]{2}{*}{ Spacing mean } & $5 \times 2$ & $55.09^{\mathrm{b}}$ & $59.00^{\mathrm{a}}$ & $57.04 \mathrm{a}$ & $45.89^{\mathrm{a}}$ & $41.52^{\mathrm{b}}$ & $43.70^{b}$ \\
\hline & $5 \times 3$ & $56.02^{\mathrm{a}}$ & $57.85^{\mathrm{b}}$ & $56.93^{b}$ & $44.95^{\mathrm{b}}$ & $43.28^{\mathrm{a}}$ & $44.11^{\mathrm{a}}$ \\
\hline \multirow[t]{3}{*}{ LSD 0.05} & Training system & 0.15 & 0.15 & 0.09 & 0.16 & 0.10 & 0.09 \\
\hline & Spacing & 0.11 & 0.10 & 0.07 & 0.11 & 0.07 & 0.06 \\
\hline & TS x Spacing & 0.22 & 0.21 & 0.14 & 0.22 & 0.15 & 0.13 \\
\hline
\end{tabular}


Data in Table 3 further reveals that fruit retention in upper part of the canopy was higher as compared to lower canopy parts irrespective of the training systems and spacings. Maximum mean retention in upper and lower canopy was recorded in $(57.54 \%$ and $54.48 \%$, respectively) in Espailer system and minimum (55.08\% and 51.57\%) in Hedge row system. Similar trend was recorded in both the years. Jackson and Plamer (1977) also found that shading treatment significantly reduced fruit retention in apple. Singh (2001) also observed that fruit retention in upper part of the canopy was significantly higher than the middle and lower canopy parts in peach planted at different spacings.

\section{Fruit drop}

Data on this aspect presented in Table 4 show that both training systems and spacings had a significant effect on the fruit drop in peach. The trees trained to Hedge row recorded maximum mean fruit drop $(46.68 \%)$ and it was significantly higher than the trees trained to $\mathrm{Y}$ shaped, V trellis and Espailer systems where mean fruit drop of $46.00 \%, 45.07 \%$ and $44.00 \%$, respectively. The lesser fruit drop in Espailer system may be due to better light interception inside the canopy which delayed ethylene production as compared to other system. Similar findings were observed by Addicot and Lynch (1955) and Jackson (1978) in apple. Data further shows that mean fruit drop in $5 \mathrm{~m} \times 3 \mathrm{~m}$ planted trees $(44.75 \%)$ was significantly lower than the trees planted at $5 \mathrm{~m} \times 2 \mathrm{~m}(46.12 \%)$. Similar trend was observed during both the year. This may be due to more fruit retention (Table 3 ) in $5 \mathrm{~m} \mathrm{x}$ $3 \mathrm{~m}$ due to less competition for metabolites and water which probably reduced fruit drop. These results are in accordance with those of reported by Byers et al., (1991) in apple.

As far as fruit drop at different canopy parts are concerned, the data further shows that fruit drop in upper part of the canopy was significantly less as compared to lower part of the canopy irrespective of training system and spacings. Decrease in fruit drop in upper part of canopy may be due to the fact that upper part is better exposed to light and had more photosynthates accumulation which could be translocated to fruits. Maximum fruit drop both in upper and lower part of the canopy was recorded in trees trained to Hedge row system and minimum in Espailer trained trees during the present studies. Jackson and Palmer (1977) also observed that shading treatments significantly increased fruit drop in apple.

\section{Relative pattern of fruiting in the tree canopy}

Data on this aspect in Table 5 show that, irrespective of training systems and spacings, maximum crop over a two year period was born in the upper part of the tree canopy as compared to the lower canopy part. More fruiting in the upper part may be due to the fact that competition for light caused partial etiolation inducing the branches to grow high for intercepting light for photosynthesis. Maximum crop in the upper part of the canopy $(66.70 \%)$ was born in trees trained to Hedge row and it was significantly higher than the trees trained to other systems. Minimum crop in the upper part $(52.21 \%)$ was born in $\mathrm{V}$ trellis trees. In the lower canopy part, maximum crop $(48.31 \%)$ was recorded in $\mathrm{V}$ trellis trees and minimum (34.29\%) in Hedge row trees. Similar trend was observed during both the years. This shows that the difference in crop borne by the upper and lower parts of the tree canopy was less in Espailer and $\mathrm{V}$ trellis trained trees as compared to Hedge row trees during the present investigations. This may be due to reduced radiation interception and penetration in the tree canopy of Hedge row trees which decreased flower bud density and fruit set in peach. Heinicke (1966) reported that availability of proper sunlight to the lower 
branches of the trees become limiting factor which adversely affected flowering, fruiting and yield of the fruits. Similar results have also been reported by Erez (1982).

Data further show that crop in the upper part of the canopy was significantly more $(57.04 \%)$ in trees planted at $5 \mathrm{~m} \mathrm{x} 2 \mathrm{~m}$ as compared to $5 \mathrm{~m} \times 3 \mathrm{~m}$ planted trees $(56.93 \%)$. Whereas in the lower canopy part, $5 \mathrm{~m} \times 3 \mathrm{~m}$ planted trees recorded significantly more fruit crop $(44.11 \%)$ as compared to $5 \mathrm{~m} \times 2 \mathrm{~m}$ planted trees $(43.70 \%)$. This may be due to reduced radiation received in the lower canopy part of $5 \mathrm{~m} \times 2 \mathrm{~m}$ planted trees which is evident during the present studies also.

\section{References}

Addicot, F. T., and Lynch R.S. 1955. Physiology of abscission. A Rev Pl Physiol 6: 211-38.

Byers, R. E., Carbaugh, D.H., Presley, C.N., and Wolf, T.K. 1991. The influence of low light on apple fruit abscission. J Hortic Sci 66(1): 7-17.

Davis, L.D. 1957. Flowering and alternative bearing. Proc Amer Soc Hort Sci 70: 545-56.

Doud, D.S and Ferree, D.C. 1980. Influence of altered light levels on growth and fruiting of mature 'Delicious' apple tree. J Am Soc Hortic Sci. 105: 325-28.

Dyankov, D. 1995. Effect of palnting distance on the development of some early apple cultivars. Rasteniev dni Nauki 32: 71-74.

Erez, A. 1982. Peach meadow orchard: two feasible systems. HortScience 17: 138-42.

Heinicke, D.R. 1963. The micro-climate of fruit trees II. Foliage and light distribution pattern in apple trees. Proc Amer Soc Hort Sci 83: 111.

Heinicke, D.R. 1966. Characteristics of 'McIntosh' and 'Red Delicious' apple as influenced by exposure to sunlight during the growth season. Proc Amer Soc Hort Sci 89: 10-13.

Jackon, J.E., and Palmer, J.W. 1977. Effects of shade on the growth and cropping of apple trees: II. Effects on components of yield. J Hortic Sci 52: 253-66.

Jackson, J. E. 1978. Utillization of light resources by HDP systems. Acta Hort 65: 61-70.

Li N., QianLi, D., HaiHong, Q., HaiDong, W., and JinHua, L. 2013. Effect of training system on fruit yield of different olive cultivars. For Res 26(4): 521-27.

Mika, A., and Piatkowski, M. 1986. Results of a 10-year trial of high-density planting of 'McIntosh' and 'Macspur' apple trees. Acta Hort 160: 293-04.

Mika, A., Chlebowska, D., and Kosmala, J. 1981. Effects of long term spacing trials with apple trees. Fruit Sci Rep 8: 101-13.

Pathak, R.K., and Pathak, R.A. 2001. Peaches. In: Temperate Fruits (Eds.) S.K., Mitra, Bose, T.K., and Rathore, D.S. Horticulture and Allied Publishers, Kolkata. Pp. 179-232.

Ristevski, B. 1982. Growth and fertility of pears planted at different distances. GodisenZbornik-na-Zemjodelskiot-Fakultet-naUnivazitetot-vo-Skpje 30: 19-30.

Singh, A. 2003. Light interception behavior of guava and its effects on vegetative growth, fruit yield and quality. Ph.D. Thesis, Punjab Agricultural University, Ludhiana, India.

Singh, H. 2001. Effect of planting densities and training systems on light interception, growth, productivity and nutrient composition of peach. Ph.D. Thesis, Punjab Agricultural University, Ludhiana, India.

Yoshikawa, F., Ramming, D.W., and Lakue, J.H. 1989. Rootsocks. In: Peaches, plums and nectarines: Growing and handling for fresh market (Eds.) J.H., LaRue, and R.S., Johnson. Divi. Agr. Nat. Resources Publishers, Univ. Calif., Oakland. Pp. 9-11.

\section{How to cite this article:}

Yamini Sharma and Harminder Singh. 2018. Effect of Various Training Systems and Spacings on Flowering and Fruiting in Peach cv. Shan-i-Punjab. Int.J.Curr.Microbiol.App.Sci. 7(02): 446-455. doi: https://doi.org/10.20546/ijcmas.2018.702.056 